\title{
EFFICENCY OF SOME ACARICIDES ON PREDATION POTENTIAL OF Amblyseius gossypi AND Coccinella undesimpunctata ASSOCIATED WITH SPIDER MITE ON COTTON PLANTS . \\ Aref, S. A. \\ Plant protection Research Institute, Giza, Dokki .
}

\begin{abstract}
Abamectin caused the highest decrease in prey eggs consumption $(56.25$ eggs) comparable to the control through the egg meal of the all days (178.80 eggs during four days). Also, Abamectin was the most effective chemical that caused decrease in adult consumption (consumption (32.55 adult during four days) comparable to the control (73.74 adult) Therefore, Abamectin reduced the adult consumption $(5.75,7.25,9.25$ and 10.50 , individ. during the first, second, third and fourth days, respectively) with the percentages of $22.63,23.35,28.87$ and $31.37 \%$, respectively. Etoxazole was the least effective compound in this respect, when $A$. gossypi fed on eggs treatment the average of total consumed eggs were 46.03 during the fourth days successively with the percentages of feeding capacity for each of the fourth days of this predator were $17.48,28.78,23.25$ and $30.97 \%$, respectively. While ,when it fed on adult of $T$. urticae, the average consumption of $A$. gossypi was 42.05 individ. through fourth days successively (73.74 individ. for control ) with the percentages of $23.18,19.61,28.35$ and $28.65 \%$, respectively. Laboratory studies carried out on the ladybird beetle predator showed that, it devoured 189.85 of the two spotted spider mite eggs during the shortest duration of larval stage (11.30 days ) compared with control (376.12 eggs) that was consumed in 10 days all larval instars. The fourth larval instar consumed the highest percentages of $T$. urticae eggs $(37.42 \%)$ (treatment). On the other hand, the larvae of $C$. undicempunctata was fed on $T$. urticae adult, the duration of larval instars lasted 9.45 days, consumed during 176.75 adults in untreatment. While the treatment by Abamectin, the consumption was 104.05 adults for the four instars during 12.50 days. The $4^{\text {th }}$ instar consumed relatively the highest percentages of individual offered four the fore mentioned mite, as it consumed were $13.21,18.02,27.63$ and $41.56 \%$, respectively.

The coccinellid larval stage was completed in four instars, with a total larval duration of 10.50 days, consumed during these days 148.05 eggs. Also, the percentage of feeding capacity for each of the four larval instars of this predator were $17.73,23.44,28.19$ and $30.90 \%$, respectively. Concerning the two spotted spider mite adult, the ladybird consumed 100.10 individ. during 12.24 days for the four larval instars. Thus, the most voracious instar was the fourth instar, that consumed $40.04 \%$ out of total consumed. While the first instar was the least voracious $(12.24 \%$ out of total consumed).
\end{abstract}

\section{INTRODUCTION}

The two spotted spider mite, Tetranychus urticae Koch (Acarina: Tetranychidae), is considered one of the most important and dangerous pests attacking and infesting a wide range of different agricultural crops such as field crops (cotton fields). chemical techniques had been the exploitation of predators which are commonly found in agricultural ecosystems (Sharaf 
Aref, S. A.

and EL-Basyouni 2002 and Saied et al. 2002). The predator mite, Amblyseius gossypi and the insect predator, Coccinella undecimpunctata L. are the most abundant natural enemies associated with spider mite on cotton plants. Those predators play an important role in suppressing populations of phytophagous mites. In this respect, many authors referred to the predators as very important factor in integrated mite management and must be safeguarded (Hamad 2005 and Mohamed 2006). this study was carried out at the farm of the Sakha Agricultural Research Station for studying the effect of acaricides on the predation potential of predator mite, A. gossypi (adult) and the coccinellid, C. undecimpunctata L. (larvae) on eggs and adult of $T$. urticae under the laboratory conditions.

\section{MATERIALS AND METHODS}

Tested compounds:

Vertimec: The common name is Abamectin (USAN).

- Formulation: $1.80 \%$ EC.(emulsifiable concentrates)

- Rate : $40 \mathrm{ml} / \mathrm{feddan}$ -

Baroke: The common name is Etoxazole

- Formulation: $10 \%$ SC. - Rate : 300ml/feddan.

Prey culture, Tetranychus urticae:

The field strain of the two-spotted spider mite, T. urticae was collected from infested leaves of cotton plants and grown in the experimental farm of Sakha Agricultural Research Station, Kafrelsheikh governorate, the collected individual were samples transferred to the laboratory in a plastic polyethylene bag, then introduced on new sweet potatoes plants and reared under laboratory conditions according to Mohamed (2006). Sweet potatoes plants were planted in the woodhouse of Sakha Agricultural Research Station in mites Department.

\section{Predators culture:}

\section{Mite predator, Amblyseius gossypi:}

This predator (adult) was obtained from cotton plants. It was transferred to the laboratory for rearing on $T$. urticae (adults) maintained on sweet potatoe plants, confined in a glass jar. It was reared under the same laboratory conditions as mentioned above for $T$. urticae culture. Adult predators of uniform age were collected from the cultures for the experimental use.

Insect predator, Coccinella undecimpunctata:

Adults of $C$. undecimpunctata were collected from the cotton plants and transferred to the laboratory. Each couple was confined in glass jar (1 liter), covered with black muslin sheet as site for oviposition, and furnished with moistened filter paper to provide enough humidity. The ladybird beetle, C. undecimpunctata was reared on T. urticae adults in Petri-dishes until oviposition occurred. Eggs were collected by means of a fine pair of scissors, transferred into Petri-dishes $(10 \mathrm{~cm})$, incubated until hatching and the colony was left to propagate. Filter papers were laid at bottoms of Petri-dishes to facilitate the movement of the predator active larvae (Farag, 2005). 


\section{Effect of tested compounds on predation efficiency: Predation efficiency of Amblyseius gossypi adult:}

For the study of predation efficiency for adult stage of $A$. gossypi number of tested predator were individually reared on adult prey, $T$. urticae under laboratory conditions. 50 adult females of $T$. urticae were transferred to each leaf discs $(4 \mathrm{~cm})$ to oviposite for 24 hours, then adult females were removed from the leaf discs and 200 eggs of $T$. urticae were found on each leaf discs, the over numbers of eggs were removed. The compounds were applied for the leaf discs after oviposite adult females of $T$. urticae, the leaf discs were sprayed by $\mathrm{LC}_{25}$ concentration of each tested acaricides ((Abamectin and Etoxazole). One adult of predator was transferred to each treated leaf disc. Each treatment was replicated four time each day as well as control, where large discs of sweet potatoes plants treatment were placed on high surfaces, and new fresh discs were placed in dishes when necessary. The number of consumed eggs by the tested predator was frequently recorded after 1,2, 3 and 4 days of applications the emerged adults were removed at once.

In case of predation efficiency test on adult, $T$. urtica, leaf discs were dipping in $\mathrm{LC}_{25}$ concentration for each tested acaricide for five seconds and left to dry, 100 individ. of $T$. urticae were transferred to each treated leaf discs in dishes by tested compounds (Abamectin and Etoxazole), an adult predator, A. gossypi was placed in four replicates for each compound as well as control each day. One individual of predator was transferred to each treated leaf discs. The presence and absence of mite were recorded after every 1, 2, 3 and 4 days from application. Also the number of consumed mite by the tested predator was recorded 1, 2, 3, 4 days from application respectively, (Hammad, 2005). The oviposited eggs were frequently recorded.

\section{Predation efficiency of Coccinella undicempunctata larvae:}

The technique was used to test the effect of the same tested compounds residues on predation efficiency of $C$. undicempunctata, larvae. 50 adult females of $T$. urtica were transferred to each leaf discs to oviposite for 24 hours, adult females were removed from the leaf discs and 100 eggs of the mite were left on each leaf disc for the first larval instar, the over numbers of eggs were removed. The leaf discs were sprayed by $\mathrm{LC}_{25}$ concentration of each tested acaricides (Abamectin and Etoxazole). Individuals of uniform age which were collected from the culture, were divided into four groups for each instar, each one moved individually to Petridishes. The numbers of eggs consumed were recorded after $24 \mathrm{hrs}$. the emerged adults of the used prey were frequently removed.

In case predation efficiency on the two spotted spider mite, $T$. urticae adult, the leaf discs were dipping in $\mathrm{LC}_{25}$ concentration of each tested compound for five second and left to dry, 100 individ. of $T$. urtica were transferred to each leaf discs treatment in dishes in the first larval instar laid into Petri-dishes.

Every morning, dishes were inspected to remove remains of the devoured prey, as well as live prey which exceeded the need of the predator. Complete new groups of $T$. urticae adults were then introduced into dishes 
Aref, S. A.

on the discs. As the predator instars progressed, number of each group of introduced prey was also increased for the need of the predator, until reached maximum (200 eggs and 120 individ. in the fourth larval instar). Number of devoured prey by each larval instars of the predator was calculated daily until pupation occurred, also if any egg was observed on disc in case predation efficiencies on adult they were killed by fine pin.

Toxicity of tested compounds on the predators, Amplyseius gossypi (adult) and Coccinella undecimpunctata (larvae):

To measure the toxic effect of tested compounds on predators, $A$. gossypi (adult) and C. undecimpunctata (larvae) all compounds were evaluated by leaf disc spray technique, concentrations (ppm) of the active ingredient for each tested compound was prepared and the leaf discs were sprayed with $\mathrm{LC}_{50}$ concentration of each tested acaricides, 200 individ. of $T$. urtica were transferred to each un treated leaf discs in dishes for feeding. Each treatment was replicated four time then 4 adults of predator, A. gossypi, and 4 larvae of predator, $C$. undecimpunctata (fourth larval instar were transferred to each leaf disc before application of compound solution. Mortality counts were made 24 hours after treatment and correction for the control mortality was made using Abbott ${ }^{\prime} s$ formula (1925).

\section{RESULTS AND DISCUSSION}

\section{Effect of acaricides on predation efficiency of $A$. gossypi:}

Discussing results, it could be noticed that successful biological control depends upon several factors concerning the predators biology, one of that important factor is the rate of prey consumption. Certainly low concentration level of compounds such as $\mathrm{LC}_{25}$ for adult mites which do not cause enough mortality can affect other responses such as functional response; this is why the prey eggs consumption was recorded under chemical treatment. The decrease in feeding capacity by $A$. gossypi and C. undicempunctata exposed to chemicals contaminated eggs on leaf discs could arise a non toxic influence of a change in the nature of the surface on which predator fed.

\section{Effect of Abamectin residues:}

Effect of Abamectin on the predation efficiency of $A$. gossypi adults the fed on $T$. urticae eggs and adults are presented in( Table 1). Results indicated that, most of the tested compounds caused a decrease in prey consumption (eggs and adults), compared with control. On the other hand, the average of total consumed eggs per one predator was 169.25 eggs throughout four days in untreated. In the first day, it consumed 18.75 eggs ( $10.52 \%$ out of total consumed eggs), in second day consumed 32.25 eggs (18.10\% out of total consumed eggs) and in the third day only, it consumed 53.50 eggs ( $29.78 \%$ out of total consumed eggs), 64.75 eggs ( $36.36 \%$ out of total consumed eggs) of them were consumed by the fourth day. On the other hand, the data shown in

Table 1 indicated that feeding with the predator, A. gossypi treated with Abamectin was decreased on the prey $T$. urticae. Abamectin caused 
high reduction in prey egg consumption compared with the control throughout the egg meal of all days, the predator, $A$. gossypi consumed 56.25 eggs, nearly three quarters of that consumed at the first day (11eggs with the percentage $19.55 \%$ of total consumed eggs). Daily eggs consumed in the two spotted spider mite were, 13.25, 15 and 17 eggs with the percentage $23.55,26.66$ and $30.2 \%$ out of total consumed eggs for the second, third and fourth days, respectively,compared with $36.36 \%$ of untreated eggs were consumed at the fourth day.

As shown in (Table 1), concerning of the predator adult fed on the two spotted spider mite adults, found on leaf discs in control, at the first day, it consumed 14.25 individuals, ( $19.32 \%$ out of total consumed adult), the second day consumed 20.25 individ. (27.46\%), the third day consumed 16.62 adult (22.53\%) and at the fourth day devoured 22.62 individ. (30.67\%).

(Table 1): Effect of Abamectin residues on predation efficiency of Amblyseius gossypi adults fed on the two spotted spider mite eggs and adults.

\begin{tabular}{|c|c|c|c|c|c|c|}
\hline \multirow{3}{*}{ Days } & \multicolumn{6}{|c|}{ No. of consumed eggs } \\
\hline & \multicolumn{3}{|c|}{ Treated } & \multicolumn{3}{|c|}{ Un-treated } \\
\hline & (No. \pm SD) & LSD 0.01 & $\%$ & (No. \pm SD) & LSD 0.01 & $\%$ \\
\hline $1^{\text {st }}$ & $11.00 \pm 0.81$ & 0.57 & 19.55 & $18.75 \pm 1.97$ & 1.39 & 10.52 \\
\hline $2^{\text {nd }}$ & $13.25 \pm 1.25$ & 0.88 & 23.55 & $32.25 \pm 2.50$ & 1.76 & 18.10 \\
\hline $3^{\text {rd }}$ & $15.00 \pm 0.81$ & 0.57 & 26.66 & $53.50 \pm 1.46$ & 1.30 & 29.78 \\
\hline $4^{\text {th }}$ & $17.00 \pm 0.80$ & 0.57 & 30.2 & $64.75 \pm 1.94$ & 1.37 & 36.36 \\
\hline Total & 56.25 & & & 169.25 & & \\
\hline Mean & 14.60 & & & 42.31 & & \\
\hline \multicolumn{7}{|c|}{ No. of consumed adult } \\
\hline \multicolumn{4}{|c|}{ Treated } & \multicolumn{3}{|c|}{ Un-treated } \\
\hline $1^{\text {st }}$ & $5.75 \pm 0.02$ & 1.42 & 22.63 & $14.25 \pm 6.25$ & 1.29 & 19.32 \\
\hline $2^{\text {nd }}$ & $7.25 \pm 0.76$ & 0.54 & 23.35 & $20.25 \pm 2.98$ & 1.03 & 27.46 \\
\hline $3^{\text {rd }}$ & $9.25 \pm 0.76$ & 0.54 & 28.87 & $16.62 \pm 6.26$ & 1.91 & 22.53 \\
\hline $4^{\text {th }}$ & $10.50 \pm 0.36$ & 0.26 & 31.37 & $22.62 \pm 4.86$ & 1.39 & 30.67 \\
\hline Total & 32.55 & & & 73.74 & & \\
\hline Mean & 8.18 & & & 18.43 & & \\
\hline
\end{tabular}

Also, results indicated that, Abamectin was the most effective compound, caused a decrease in consumption adult, comparable to the control, it is apparent from the calculated average number of adult consumed by one adult predator through the first, second, third and fourth days, that Abamectin was the most effective compound that reduced the prey adult consumption (5.75, 7.25, 9.25 and 10.50, individ. during the first, second, third and four days, respectively). The percentages of the feeding capacity for each of the fourth days of this predator, were 22.63, 23.35, 28.87 and $31.37 \%$, respectively. Hosny and keratum (1995) and Keratum (2000) found that decrease feeding in case of the predator mite, $A$. fallacis when fed on prey, T. urticae treated with Deltamethrin Abou-Awad and El-Banhaawy (1985) mentioned that the increase in the daily consumption of prey $T$. urticae treated with Cypermethrin caused an increase in mortality at high predator density. Ford et al. (1989) found a reduction in the number of eggs eaten by Amplyseius fallacis on treated discs with Deltamethrin. 
Aref, S. A.

\section{Effect of Etoxazole residues:}

Data shown in (Table 2) indicated that Etoxazole caused the highest reduction in prey egg consumption comparable to the Abamectin. When the predator, A. gossypi adults fed on treated eggs of the two spotted spider mite, the average of total eggs consumed per predator adult were 8.50, 13. 25, 10.75 and 14.25 eggs for the first, second, third and four days, respectively. At the first day, $17.48 \%$ of the total number of eggs consumed, by the third day, as it consumed $23.35 \%$, followed the second day $(28.78 \%)$, and the fourth day was $30.97 \%$, respectively.

(Table 2): Effect of Etoxazole residues on predation efficiency of Amplyseius gossypi adult fed on the two spotted spider mite eggs and adult.

\begin{tabular}{|c|c|c|c|c|c|c|}
\hline \multirow{3}{*}{ days } & \multicolumn{6}{|c|}{ No. of consumed eggs } \\
\hline & \multicolumn{3}{|c|}{ treatment } & \multicolumn{3}{|c|}{ untreatment } \\
\hline & (No. \pm SD) & LSD 0.01 & $\%$ & (No. \pm SD) & LSD 0.01 & $\%$ \\
\hline $1^{\mathrm{st}}$ & $8.50 \pm 0.85$ & 0.60 & 17.48 & $18.75 \pm 1.97$ & 1.39 & 10.52 \\
\hline $2^{\text {nd }}$ & $13.25 \pm 1.75$ & 0.54 & 28.78 & $32.25 \pm 2.50$ & 1.76 & 18.10 \\
\hline $3^{\text {rd }}$ & $10.75 \pm 1.97$ & 1.39 & 23.35 & $53.50 \pm 1.46$ & 1.30 & 29.78 \\
\hline $4^{\text {th }}$ & $14.25 \pm 1.25$ & 0.88 & 30.97 & $64.75 \pm 1.94$ & 1.37 & 36.36 \\
\hline Total & 46.75 & & & 169.25 & & \\
\hline Mean & 11.68 & & & 42.31 & & \\
\hline \multicolumn{7}{|c|}{ No. of consumed adult } \\
\hline \multicolumn{4}{|c|}{ Treatment } & \multicolumn{3}{|c|}{ untreatment } \\
\hline $1^{\text {st }}$ & $9.75 \pm 1.80$ & 1.27 & 23.18 & $14.25 \pm 6.25$ & 1.29 & 19.32 \\
\hline $2^{\text {nd }}$ & $8.25 \pm 0.78$ & 0.17 & 19.61 & $20.25 \pm 2.98$ & 1.30 & 27.46 \\
\hline $3^{\text {rd }}$ & $12.00 \pm 0.47$ & 0.35 & 28.53 & $16.62 \pm 6.26$ & 1.91 & 22.53 \\
\hline $4^{\text {th }}$ & $12.50 \pm 1.46$ & 1.06 & 28.65 & $22.62 \pm 4.86$ & 1.39 & 30.67 \\
\hline Total & 42.50 & & & 73.74 & & \\
\hline Mean & 10.51 & & & 18.43 & & \\
\hline
\end{tabular}

While, the adult of $A$. gossypi fed on the two spotted spider mite, $T$. urticae adult was the average consumption 9.75 adults $(23.18 \%$ of the total number of the adults consumed) in the first day, while in the second, third and the fourth days, it consumed 8.25, 12 and 12.50 adults $(19.61,28.53$ and $28.65 \%$, respectively).

On the other hand, adults of $A$. gossypi fed on untreated $T$. urticae eggs and adults consumed during the four days 169.25 and 73.74, respectively. Kim and paik (1996) found that the Hydrocarbon oils were of moderate effect concerning the egg consumption by the predator and egg production

\section{Effect of acaricide residues on predation efficiency of Coccinella undicempunctata: \\ Effect of Abamectin residues:}

Durations and the predation efficiency of $C$. undicempunctata L. larvae fed on $T$. urticae eggs are presented in (Table 3). Throughout the total larval instars duration (10.00 days), the predator consumed 376.12 untreated eggs of T. urticae compared with Abamectin treatment 190.75 (eggs), that was completed in 11.50 days, during which it consumed 49, 91.25, 111.37 and 124.50 eggs for the four larval instars, respectively. Abamectin showed 
moderate effect on consumption by the predator, ladybird when it fed on treated eggs of $T$. urticae, ( leaf discs treatment), which was, 25, 32.75 and 61.50 eggs in the first, second and third instar, respectively, While it was 71.50 egg by the fourth larval instar only .In case used Abamectin, the percentages of feeding capacity for each of the four larval instars of this predator were $13.16,17.25,32.15$ and $37.42 \%$, respectively. When the larvae of C. undicempunctata L. were fed on untreated adults of T. urticae , the duration of larval instars was 9.45 days during which it consumed during 176.75 adult, the first larval instar consumed 19.50 adult $(11.03 \%$ of the total number of eggs consumed), the second larval instar consumed 39.25 adult $(22.20 \%)$, the third larval instar consumed 46.00 adult $(26.02 \%)$, and also, most of them were consumed by the fourth larval instar (72 adult, $40.73 \%$ ) of the two spotted spider mite. On the other hand, the treatment with Abamectin showed a decrease in the consumption which it was $13.75,18.75,28.75$, and 43.25 adults by the first, second, third and fourth instars, respectively. The percentage of feeding capacity for each of the four larval instars of this predator was $13.21,18.02,27.63$ and $41.56 \%$, respectively. Mohamed (2006) reported that Abamectin and Cypermethrin were the most effective compounds that reduced the prey eggs consumption by the predator, $S$. gilvifrons (25.25 eggs for Abamectin compared with control of 65 eggs). Elfakharany (2005) found that positive significant correlation between $C$. undicempunctata and T. urticae. Boraei et al. (2009) found that the duration of C. undicempunctata fed on $T$. urticae was 10 days during which it consumed about 376 individ.

(Table 3): Effect of Abamectin residues on predation efficiency of Coccinella undecimpunctata larvae fed on the two spotted spider mite eggs and adult.

\begin{tabular}{|c|c|c|c|c|c|c|}
\hline \multirow[t]{3}{*}{ Larval instars } & \multicolumn{6}{|c|}{ No. of consumed eggs } \\
\hline & \multicolumn{3}{|c|}{ Treated } & \multicolumn{3}{|c|}{ un Treated } \\
\hline & No. \pm SD & LSD 0.01 & $\%$ & (No. \pm SD) & LSD 0.01 & $\%$ \\
\hline $1^{\text {st }}$ & $25.00 \pm 0.81$ & 0.57 & 13.16 & $49.00 \pm 2.50$ & 0.57 & 13.20 \\
\hline $2^{\text {nd }}$ & $32.75 \pm 3.14$ & 2.22 & 17.25 & $91.25 \pm 4.60$ & 1.51 & 24.26 \\
\hline $3^{\text {rd }}$ & $61.50 \pm 1.46$ & 1.30 & 32.15 & $111.37 \pm 3.21$ & 1.56 & 29.61 \\
\hline $4^{\text {th }}$ & $71.50 \pm 1.46$ & 1.30 & 37.42 & $124.50 \pm 4.20$ & 1.30 & 33.10 \\
\hline Total & 190.75 & & & 376.12 & & \\
\hline Mean & 47.68 & & & 94.30 & & \\
\hline Duration (days) & 11.50 & & & 10.00 & & \\
\hline \multicolumn{7}{|c|}{ No. of consumed adult } \\
\hline \multicolumn{4}{|c|}{ Treated } & \multicolumn{3}{|c|}{ Un Treated } \\
\hline $1^{\mathrm{st}}$ & $13.75 \pm 2.20$ & 1.42 & 13.21 & $19.50 \pm 1.29$ & 1.30 & 11.03 \\
\hline $2^{\text {nd }}$ & $18.75 \pm 1.97$ & 1.39 & 18.20 & $39.25 \pm 1.46$ & 1.30 & 22.20 \\
\hline $3^{\text {rd }}$ & $28.75 \pm 3.86$ & 2.73 & 27.63 & $46.00 \pm 2.23$ & 1.21 & 26.02 \\
\hline $4^{\text {th }}$ & $43.25 \pm 3.40$ & 2.15 & 41.56 & $72.00 \pm 2.23$ & 1.58 & 40.73 \\
\hline Total & 104.50 & & & 176.75 & & \\
\hline Mean & 26.12 & & & 44.18 & & \\
\hline Duration (days) & 12.50 & & & 9.45 & & \\
\hline
\end{tabular}

\section{Effect of Etoxazole residues:}

As shown in (Table 4), results obviously revealed that Etoxazole caused highly toxic, effect when the predator, fed on treated eggs of $T$. 
Aref, S. A.

urticae. Duration of the four larval instars was 10.50 days compared with control ( 10 days ). The predator larvae, C. undecimpunctata consumed $26.25,34.75,41.75$ and 45.75 eggs during the first, second, third and fourth instars, respectively. with percentage of feeding capacity for each of the four larval instars of $17.73,23.44,28.19$ and $30.90 \%$, respectively. Therefore, the fourth larval instar was the most efficient instar. The duration of the four larval insters was 12.24 days, when the predator or larvae of $C$. undecimpunctata fed on treated adult of $T$. urticae with Etoxazole.

(Table 4): Effect of Etoxazole residues on predation efficiency of Coccinella undecimpunctata larvae fed on the two spotted spider mite eggs and adult.

\begin{tabular}{|c|c|c|c|c|c|c|}
\hline \multirow{3}{*}{ Larval instars } & \multicolumn{6}{|c|}{ No. of consumed eggs } \\
\hline & \multicolumn{3}{|c|}{ Treated } & \multicolumn{3}{|c|}{ un Treated } \\
\hline & No. \pm SD & LSD 0.01 & $\%$ & (No. \pm SD) & LSD 0.01 & $\%$ \\
\hline $1^{\text {st }}$ & $26.25 \pm 2.87$ & 2.30 & 17.73 & $49.00 \pm 2.50$ & 0.57 & 13.20 \\
\hline $2^{\text {nd }}$ & $34.75 \pm 2.36$ & 1.67 & 23.44 & $91.25 \pm 4.06$ & 1.51 & 24.26 \\
\hline $3^{\text {rd }}$ & $41.75 \pm 3.68$ & 2.60 & 28.19 & $111.37 \pm 3.21$ & 1.56 & 29.61 \\
\hline $4^{\text {th }}$ & $45.75 \pm 1.93$ & 1.36 & 30.90 & $124.50 \pm 4.20$ & 1.30 & 33.10 \\
\hline Total & 148.50 & & & 376.12 & & \\
\hline Mean & 37.12 & & & 94.30 & & \\
\hline Duration(days) & 10.50 & & & 10.00 & & \\
\hline \multicolumn{7}{|c|}{ No. of consumed adult } \\
\hline \multicolumn{4}{|c|}{ Treated } & \multicolumn{3}{|c|}{ un Treated } \\
\hline $1^{\text {st }}$ & $12.25 \pm 2.14$ & 1.51 & 12.24 & $19.50 \pm 1.29$ & 1.30 & 11.03 \\
\hline $2^{\text {nd }}$ & $18.50 \pm 1.46$ & 1.30 & 18.40 & $39.25 \pm 1.46$ & 1.30 & 22.20 \\
\hline $3^{\text {rd }}$ & $29.75 \pm 1.97$ & 1.39 & 29.74 & $46.00 \pm 2.23$ & 1.21 & 26.02 \\
\hline $4^{\text {th }}$ & $40.50 \pm 1.46$ & 1.30 & 40.40 & $72.00 \pm 2.23$ & 1.58 & 40.73 \\
\hline Total & 100.00 & & & 176.75 & & \\
\hline Mean & 25.00 & & & 44.18 & & \\
\hline Duration(days) & 12.24 & & & 9.45 & & \\
\hline
\end{tabular}

The first larval instar of the predator consumed 12.25 individ. (12.24\% out of total consumed), the second instar consumed 18.05 adult (18.04\%), the third instar consumed 29.75 adult (29.74\%) and the fourth larval instar was the highly efficient one as it consumed spider mite adult of 40.05 individuals which represented $40.50 \%$ of the total consumption. On the other hand, the data of this study shown in (Table 4) indicated that Etoxazole cause high reduction in prey eggs and adult consumption ( 148.50 eggs and 100 individ. in 10.50 and 12.24 days, respectively) compared with the control through the eggs and adult meal of the all days, in which the predator, $C$. undecimpunctata larvae consumed 376.12 eggs and 176.75 individ. in 10 and 9.45 days, respectively. Boraei et al (2009) indicated that of $C$. undecimpunctata larvae consumed 376 eggs of $T$. urticae during all the four larval instars. Mohamed (2006) reported that Etoxazole was the least effective compound compared with control, the rate of eggs consumption of the spider mite, $T$. urticae by the predator insect, S. gilvifrons was 56 eggs/ day.

In general, Abamectin was less effective than Etoxazole on egg consumption by the predators. Abamectin was more effective than Etoxazole on mite adult consumption. On the other hand, results showed a decrease 
feeding capacity of the predators, $A$. gossypi adult and $C$. undecimpunctata larvae, and an increase in mortality of $A$. gossypi as a daily consumption of prey $T$. urticae treated with the acaricides. The presence of a chemical and the morphological features of the host plant may disturb the searching activities of the predators to find its food eggs stage. In spite of the egg stage of spider mite is the main food of the predators, A. gossypi and C. undecimpunctata, the leaf surface may have a negative or positive chemical stimuli that determine or evaluate the predation process.

\section{REFERENCES}

Abbott, W.S. (1925). A method of comparing effectiveness of an insecticide. J. Econ. Entomol., 18:265-267.

Abou-Awad, B.A. and E.M. El-Banhaawy (1985). Comparison between the toxicity of synthetic pyeroids to the predacious mite Amblyseius gossypi (Mesostigmata: phytoseiidae). Experimental \& Applied Acarology, (1) : 185-191.

Boraei, H. A.; A. E. Youssef; M. A. Hammad; S. A. Aref and A. A. Farag (2009). Biology and chemical control for Tetranychus urticae (Acari. : Tetranychidae). Egept. J. of Appl. Sci., 24(10B): 654-660.

EL-Fakharany, S.K.M. (2005). Integrated control of some vegetable crops pests in Kafr EL-Sheikh province. Ph.D. Thesis, Fac. Agric., Tanta Univ.,157 pp.

Farag, A.A.I. (2005). Serological studies on the relationship between some insect pests and their predators. M.Sc. Thesis, Fac. of Agric. Kafr ELSheikh, Univ.,102pp.

Ford, J.B.; A.H. Hosny and A.Y. keratum (1989). The influence of deltamethrin on the distribution of mites the $7^{\text {th }}$ Arab pesticides Conf. Tanta Univ. Sept., 11-12:33-43.

Hammad, R.A. (2005). Integrated mite management. M.Sc. Thesis, Fac. of Agric. Kafr EL-Sheikh, Univ.,174pp.

Hosny, A.H. and A.Y. Keratum (1995). Effect of deltamethrin residues on the predatory mite Amblyseius fallacies $35^{\text {th }}$ Science Week, Syrian Arab Republic Supreme Council of Sciences. Auditoriums of Tishreen Uishreen Univ./ Lattakia, 4-9 November.

Keratum, A.Y. (2000). Efficiency of some pesticides against the two spotted spider mite, Tetranychus urticae and its predator, Amblyseius gossypi. J. Agric. Res. Tanta Univ., 26(2): 418-438.

Kim, S.S. and C.H. paik (1996). Comparative toxicity of Fenpyroximate to the predatory mite Amblyseius womerslelyi (schicha) and kanazawa spider mite Tetranychus kanazawa (kishida) Acarina: phytoseiidae, Tetranychidae). Applied. Entomol. Zoology., 31(3): 369-377.

Mohamed, H.A. (2006). Integrated mite management. M.Sc. Thesis, Fac. of Agric. Kafr EL-Sheikh., Univ., 133pp.

Saied, A.A.; F.A. Shahien; A.M. Hamid and E.S. EL- Zahi (2002). Effect of certain natural and specific materials on some sucking pest and their associated natural enemies in cotton crop. $2^{\text {nd }}$ Inter. Conf. plant protect. Res. Institute, Cairo, Egypt, 21-24 December. 
Aref, S. A.

Sharaf, F.H. and S.A. El-Basyouni (2002). Searching for chemicals can be used in aphid management in cotton field. $2^{\text {nd }}$ Inter. Conf. Plant Prodect Res. Instit. Cairo, Egypt, 21-24. Dec.

تأثير بعض مبيدات العناكب على الكفاءة الافتراسية لمفترس (امبلسيس جوسيباى-

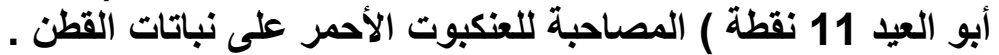
صفوت عبد السلام عارف معهد بحوث وقاية النباتات ـ الدقي - جيزة

تأثثير مركب الاباميكتين على الكفاءة الافتراسية لمفترس امبلسيس جوسيباى على بعض أطوار

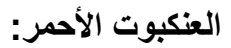

* عند تغذية مفترس الامبلسيس على بيض العنكبوت الأحمر المعامل بالابامكتين بطريقة الرش على الإنى

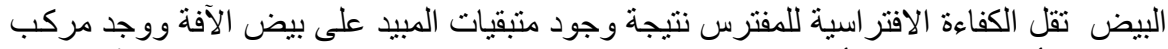

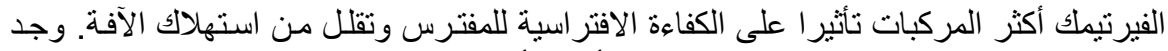

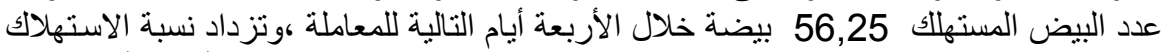
على البيض الغير معامل فوجد عدد البيض الستتهلك 178,80 بيضـة خلال الأربعة أيام التالية الئة للمعاملة.

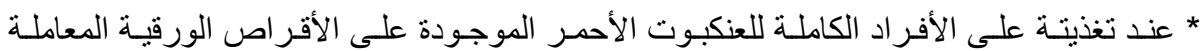

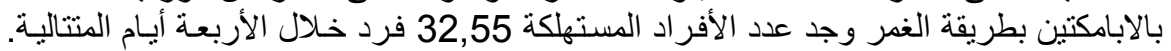

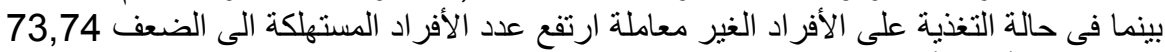
فرد خلال الأربعة أيام المنتالية. تأثير مركب ايتوكسازول على الكفاءة الافتراسية لمفترس امبلسيس جوسيباى على بعض أطوار

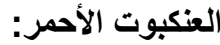

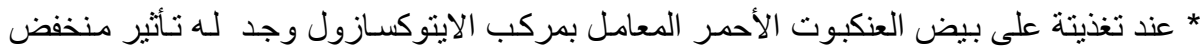

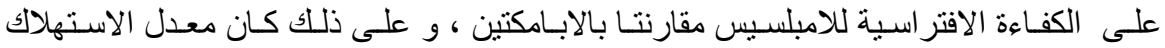

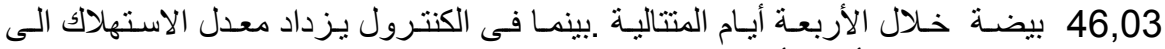
178.80 بيضة خلال الأربعة أيام التالية للمعاملة.

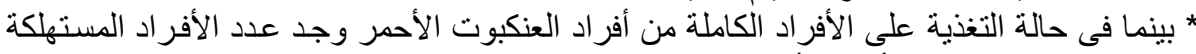

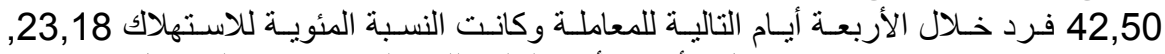

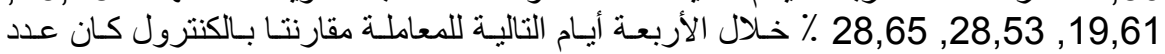
الأفر اد المستهلكة 73,74 فرد خلال الأربعة أيام المتتالية. تأثثر مركب الاباميكتين على الكفاءة الافتراسية لمفترس أبو العيد 11 نقطة على بعض أطوار

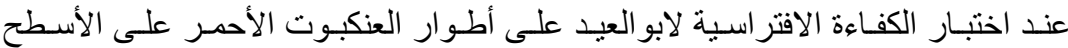

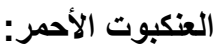

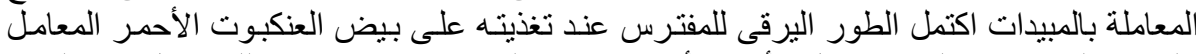

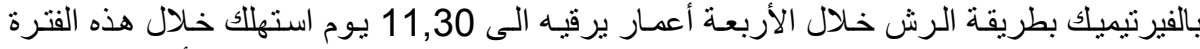

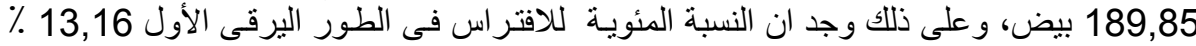




عند تغذية يرقات أبو العيد على الأفراد الكاملة للاكا روس المعامل بالابامكتين بطريقة ل اللمفترسز فئرس

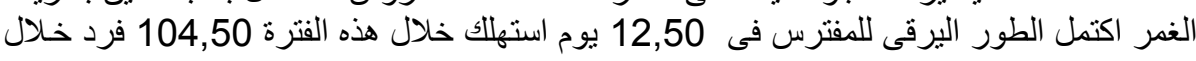




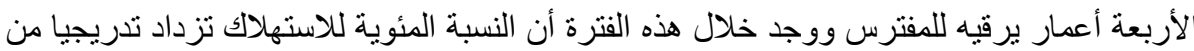

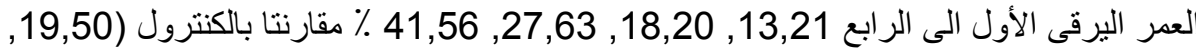

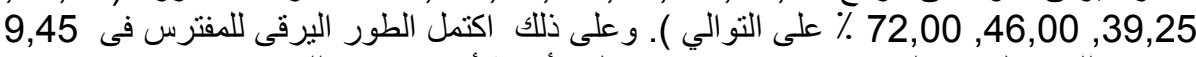

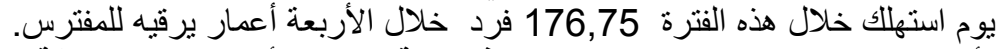

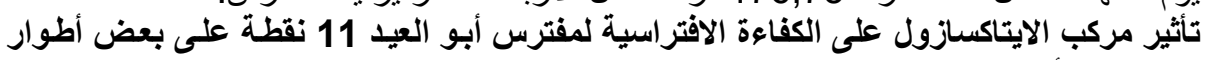
* عند اختبار الكفاءة الافتر اسية لأبو العبد 11 نقطة على ببض العنكبوت الأحمر المعامل بطريقة

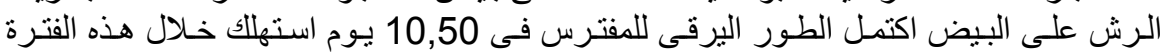

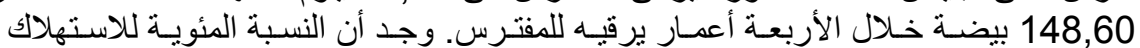







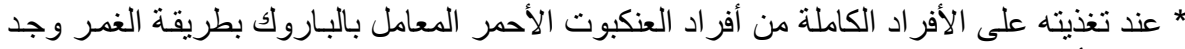



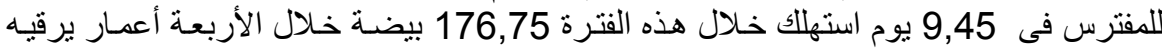
للمفترس.

كلية الزراعة - جامعة المنصورة مركز البحوث الزراعية
قام بتحكيم البحث أ.ـد / سلوى السعيد نجم البحث

أ.د / محمد عبد المحسن سلامه اله 